\title{
Erratum to: The assessment of bone mineral content and density of the lumbar spine and proximal femur in US submariners
}

\author{
H. G. Gasier • L. M. Hughes • C. R. Young •
}

A. M. Richardson

Published online: 15 July 2014

(C) International Osteoporosis Foundation and National Osteoporosis Foundation 2014

Erratum to: Osteoporos Int

DOI 10.1007/s00198-014-2753-y

The last author's name was wrongly given as A. R. Richardson; the correct name is A. M. Richardson.

The online version of the original article can be found at http://dx.doi.org/ 10.1007/s00198-014-2753-y.

L. M. Hughes $\cdot$ C. R. Young

Department of Submarine Medicine \& Survival Systems, Naval

Submarine Medical Research Laboratory, Box 900,

Groton 06349, CT, USA

H. G. Gasier $(\bowtie)$

Center for Hyperbaric Medicine \& Environmental Physiology, Duke

University Medical Center, DUMC, 3823 Bldg. CR II, Durham,

NC 27710, USA

e-mail: heath.gasier@dm.duke.edu

A. M. Richardson

Department of Pediatrics, Baystate Children's Hospital, Springfield,

MA 01199, USA 